\title{
The influence of activity and size of meals on caloric response in women
}

\author{
BY YOLA E. SWINDELLS \\ Department of Nutrition, University of Otago School of Home Science, \\ Dunedin, New Zealand
}

(Received 31 December 1970-Accepted 28 fune I97I)

\begin{abstract}
I. The oxygen utilization of ten women was measured after consuming meals supplying $230-1200 \mathrm{kcal}(0.96-5.02 \mathrm{MJ})$ in three experiments.

2. In the first experiment four subjects consumed one-ninth, one-third or one-half of the daily allowance and the oxygen consumption was measured for $3 \mathrm{~h}$ after the meal. The response was unrelated to the size of the meal.

3. Resting conditions were rigidly controlled in the second experiment. Each woman reclined on a bed for $5-7 \mathrm{~h}$ while the effect of a meal providing 600 or $900 \mathrm{kcal}(2.5 \mathrm{I}$ or $3.77 \mathrm{MJ})$ for the two lighter subjects and 800 or $12,00 \mathrm{kcal}\left(3^{\circ} 35\right.$ or $\left.5^{\circ} \mathrm{02} \mathrm{MJ}\right)$ for two heavier subjects was measured. A greater increment in energy expenditure was obtained after the larger meal for each subject. The effect of two $30 \mathrm{~min}$ walks before and after the large meal was negligible.

4. In a third experiment the effect of exercise was measured with five women consuming $900 \mathrm{kcal}(3.77 \mathrm{MJ})(a)$ followed by $5 \mathrm{~h}$ rest and $(b)$ preceded and followed by exercise (two $30 \mathrm{~min}$ walks on a treadmill). The energy increment during $90 \mathrm{~min}$ after the meal was equivalent in $(a)$ to $15 \mathrm{kcal}(63 \mathrm{~kJ})$ per $\mathrm{h}$ and in $(b)$ to $16 \mathrm{kcal}(67 \mathrm{~kJ})$ per $\mathrm{h}$, whereas the response following exercise but without food was insignificant.
\end{abstract}

After the ingestion of food there is an increased transient energy output usually referred to as the specific dynamic activity, the thermic effect or the caloric response. Bradfield, Curtis \& Margen (1968) reported that the caloric response of obese women was increased slightly by exercise. To ascertain whether a similar effect might be observed with women of lighter weight, the response of five women to a $900 \mathrm{kcal} \mathrm{meal}$ was measured while at complete rest or after walking on a treadmill. The response to meals of different size was also determined as a follow-up to a study of the metabolic effects of the frequency of meals (Swindells, Holmes \& Robinson, I968). The response to exercise in our experiments was insignificant when compared with the response to the ingestion of food.

\section{METHODS}

\section{Subjects}

The subjects were ten healthy women whose age, height and weight are given in Table . All were staff or students in our nutrition department and were familiar with the procedures used in indirect calorimetry. Subjects $G, M, D$ and $S$ had taken part in an earlier metabolic balance study (Swindells et al. 1968). Subject $S$ took part in all three experiments and subject D in Expts $\mathrm{I}$ and 2. 


\section{Procedure}

Expts 1,2 and 3 were carried out in $1967,1968,1969$ respectively to test the metabolic response (expressed as increment in energy expenditure) to single meals of varying size with or without accompanying exercise. Each experiment was divided into two or three regimens $(a, b$ and $c)$ and the measurements were made on isolated days. Each test day was preceded by a $\mathrm{I} 2 \mathrm{~h}$ overnight fast; on arrival at the laboratory in the morning the subjects rested for $40 \mathrm{~min}$ before two or three measurements of fasting metabolism were taken. The routine for the three experiments is summarized in Table 2.

Table I. Description of the ten women at the time of the experiments

\begin{tabular}{|c|c|c|c|c|c|}
\hline Expt no. & Date of expt & Subject & Age (years) & Height $(\mathrm{cm})$ & Weight $(\mathrm{kg})$ \\
\hline I & August 1967 & $\begin{array}{l}G \\
M \\
D \\
S\end{array}$ & $\begin{array}{l}19 \\
20 \\
22 \\
41\end{array}$ & $\begin{array}{l}\mathrm{I} 54 \\
\mathrm{I} 6 \mathrm{x} \\
\mathrm{I} 69 \\
\mathrm{I} 63\end{array}$ & $\begin{array}{l}48 \cdot 7 \\
54 \cdot 1 \\
78 \cdot a \\
66 \cdot 2\end{array}$ \\
\hline 2 & November 1968 & $\begin{array}{l}A \\
\text { R } \\
D \\
S\end{array}$ & $\begin{array}{l}23 \\
27 \\
23 \\
42\end{array}$ & $\begin{array}{l}160 \\
159 \\
169 \\
163\end{array}$ & $\begin{array}{l}56 \cdot 4 \\
47 \cdot 2 \\
76 \cdot 6 \\
66 \cdot 7\end{array}$ \\
\hline 3 & April 1969 & $\begin{array}{l}\mathrm{L} \\
\mathrm{E} \\
\mathrm{K} \\
\mathrm{C} \\
\mathrm{S}\end{array}$ & $\begin{array}{l}21 \\
22 \\
21 \\
21 \\
42\end{array}$ & $\begin{array}{l}157 \\
161 \\
162 \\
163 \\
163\end{array}$ & $\begin{array}{l}52 \cdot 4 \\
53.5 \\
57.0 \\
57 \cdot 0 \\
67.3\end{array}$ \\
\hline
\end{tabular}

Measurements of energy expenditure were timed from the mid-point of each meal and were taken with the subjects sitting up in bed or walking at $5.3 \mathrm{~km} / \mathrm{h}$ on a treadmill. In the exercise experiments the walking was timed so that a resting measurement could be made exactly $90 \mathrm{~min}$ after the meal and at least ro min after the end of the exercise. Each walk on the treadmill lasted for $3^{\circ}$ min with measurements of energy expenditure taken at 7 and 20 min after the start of the walk.

Expt $\mathrm{r}$. This was a direct follow-up of the study on meal frequency (Swindells et al. I 968 ; Sharpe \& Robinson, 1970) and the four women took meals of the same size as previously used. Each 30 min period started with a measurement of resting energy expenditure, after which a drink of water was taken and urine was collected for a simultancous measurement of urea excretion (Rees, 1967 ). Urea was estimated by the method of Southgate \& Barrett (rg66); after the meal urine was collected for $3-4$ h but oxygen utilization was measured for $3 \mathrm{~h}$. In Expt $\mathrm{x}(a)$ the meal was equivalent to oneninth of the daily calorie allowance for each subject; in Expts $\mathrm{I}(b)$ and $\mathrm{I}(c)$ the meal sizes were equivalent to one-third and one-half of the daily calorie allowance respectively. In Expt I (a) the subjects consumed two 'nibbles' at 09.20 and 11 .00 hours. The sizes of meals were based on daily intakes for G, M, D and S of 2040, 2140,2400 and $2560 \mathrm{kcal}(8 \cdot 54,8 \cdot 95,10 \cdot 04$ and $10 \cdot 7 \circ \mathrm{MJ})$ respectively, as estimated from chemical analysis of the diet (Swindells et al. 1968). For subjects D and $\mathrm{S}$ an additional experiment was carried through without food.

Expt 2. In Expts $2(a)$ and $(b)$ the subjects reclined in bed, reading or listening to 
the radio, and sat up in bed only to take the meal or for measurements of energy expenditure. The two lighter subjects $\mathrm{A}$ and $\mathrm{R}$ ate meals supplying $600 \mathrm{kcal}$ in Expt $2(a)$ and $900 \mathrm{kcal}$ in Expt $2(b)$, while for D and $\mathrm{S}$ the sizes were $800 \mathrm{kcal}$ and $\mathrm{r} 200 \mathrm{kcal}$ respectively. The response to the meal was measured for $3 \mathrm{~h}$ in Expt $2(a)$ and $5 \mathrm{~h}$ in Expt $2(b)$. In Expt 2 (c) two 30 min walks (see Table 2) were taken immediately before and after a meal of the same size as in Expt $2(b)$ for each subject. For subjects D and $\mathbf{S}$ an additional exercise experiment was carried through with no food taken.

Table 2. Routine followed in experiments giving $(A)$ time of day that rest, fasting measurements, meals and exercise were begun, $(B)$ the timing of the postprandial measurements of energy expenditure based on the mid-point of each meal for each subject and $(C)$ the size of each meal

$\overbrace{(a) \quad(b) \quad(c)}^{\text {Expt I }}$

$\overbrace{(\text { a }) \quad(b) \quad(c)}^{\text {Expt } 2}$

Expt 3

(A) Time of day (hours)

$\begin{array}{lccccccccc}\text { Rest } & 08.00 & 08.00 & 08.00 & 08.00 & 08.00 & 07.30 & 08.00 & 07.30 & 07.30 \\ \text { Fasting measure- } & 08.40 & 08.40 & 08.40 & 08.40 & 08.40 & 08.10 & 08.40 & 08.10 & 08.10 \\ \text { ments } & 09.00 & 09.00 & 09.00 & 09.00 & 09.00 & 08.30 & 09.00 & 08.30 & 08.30 \\ & & & & 09.20 & 09.20 & 08.50 & 09.20 & 08.50 & 08.50 \\ \text { Exercise I } & - & - & - & - & - & 09.05 & - & 09.05 & 09.05 \\ \text { Meal r } & 09.20 & 09.20 & 09.20 & 09.35 & 09.35 & 09.40 & 09.35 & 09.40 & - \\ \text { Exercise 2 } & - & - & - & - & - & 10.45 & - & 10.45 & 10.45 \\ \text { Meal 2 } & \text { I1.00 } & - & - & - & - & - & - & - & -\end{array}$

\begin{tabular}{|c|c|c|c|c|c|c|c|c|c|}
\hline \multirow{4}{*}{$\begin{array}{l}\text { Postprandial } \\
\text { resting energy } \\
\text { expenditure } \\
\text { measurements }\end{array}$} & \multirow{2}{*}{30} & \multirow{2}{*}{30} & \multirow[b]{2}{*}{30} & 20 & 20 & \multirow{2}{*}{$\begin{array}{l}20 \\
40\end{array}$} & 20 & \multirow{2}{*}{$\begin{array}{l}20 \\
40\end{array}$} & \multirow{2}{*}{$\begin{array}{l}20 \\
40\end{array}$} \\
\hline & & & & 40 & 40 & & 40 & & \\
\hline & 60 & 60 & 60 & 60 & 60 & - & 60 & - & - \\
\hline & 90 & 90 & $9 \circ$ & 90 & 90 & 90 & 90 & 90 & 90 \\
\hline & - & 120 & 120 & 120 & 120 & I 20 & 120 & 120 & 120 \\
\hline & 150 & 150 & 150 & I 50 & 150 & 一 & I 50 & 150 & I 50 \\
\hline & I 80 & 180 & 180 & 180 & 180 & - & 180 & 180 & - \\
\hline & 210 & 一 & - & - & 210 & $\therefore$ & $2 \pi 0$ & 210 & - \\
\hline & - & 一 & - & - & 240 & - & 240 & 240 & - \\
\hline & - & - & - & - & 270 & - & 270 & 270 & - \\
\hline & - & - & -- & - & 300 & - & 300 & 300 & - \\
\hline \multicolumn{10}{|c|}{ (C) Size of each meal } \\
\hline kcal & $\begin{array}{c}230- \\
280\end{array}$ & $\begin{array}{c}680- \\
850\end{array}$ & $\begin{array}{l}1020- \\
1280\end{array}$ & $\begin{array}{c}600- \\
800\end{array}$ & $\begin{array}{l}900- \\
\times 200\end{array}$ & $\begin{array}{l}900- \\
1200\end{array}$ & 900 & 900 & 0 \\
\hline $\mathrm{MJ}$ & $\begin{array}{c}0.96- \\
I \cdot 17\end{array}$ & $\begin{array}{c}2 \cdot 85- \\
3.56\end{array}$ & $\begin{array}{c}4.27- \\
5.35\end{array}$ & $\begin{array}{c}2 \cdot 51- \\
3 \cdot 35\end{array}$ & $\begin{array}{c}3.77^{-} \\
5.02\end{array}$ & $\begin{array}{c}3.77^{-} \\
5.02\end{array}$ & 3.77 & 377 & o \\
\hline
\end{tabular}

Expt 3. Each subject consumed a $900 \mathrm{kcal}(3 \cdot 77 \mathrm{MJ})$ meal; otherwise Expts $3(a)$ and $(b)$ followed the same routine as Expts $2(b)$ and $(c)$ respectively. The routine of Expt $3(b)$ was repeated by the five women in $\operatorname{Expt} 3(c)$ but without food. The response was measured for 5 h after the meal in Expts $3(a)$ and $(b)$ but Expt $3(c)$ was of shorter duration (see Table 2).

\section{niet}

Each meal consisted of meat loaf, ice-cream and black coffee as used in our earlier studies (Swindells et al. 1968). The subjects drank $200 \mathrm{ml}$ (one cup) coffee following each meal and a further $200 \mathrm{ml}$ at approximately $\mathrm{r} 2.00$ hours in those experiments 
measuring the response for $5 \mathrm{~h}$. The preparation and analysis of the diet have been described elsewhere (Holmes, Swindells, Sharpe, Wright \& Robinson, I969). In the three experiments the following amounts of ice-cream were consumed by each subject: $42 \mathrm{~g}(75 \mathrm{kcal})$ in Expt I $(a), 125 \mathrm{~g}(220 \mathrm{kcal})$ in Expts I $(b)$ and $2(a)$, and $\mathrm{I} 88 \mathrm{~g}(330 \mathrm{kcal})$ in Expts I $(c), 2(b),(c), 3(a)$ and $(b)$. The quantities of meat loaf were varied to supply the balance of the calories.

\section{Energy expenditure}

Oxygen utilization was measured for 7-10 min with a Max Planck respirometer in walking experiments and a Douglas bag for resting. Expired air was analysed in a Servomex paramagnetic oxygen analyser (Servomex Controls Ltd, Crowborough, Sussex, England) and energy expenditure was calculated according to the method of Weir (1949).

\section{RESULTS}

Table 3 gives the mean results (with standard errors of the means) for the energy expenditure $(\mathrm{kcal} / \mathrm{min})$ of each subject after meals equivalent to $(a)$ one-ninth, $(b)$ one-third and $(c)$ one-half of the daily calorie allowance in Expt $\mathbf{I}$. The fasting resting metabolism ranged in (a) from 0.73 to $1.70 \mathrm{kcal}$ per min for the four women, in $(b)$

Table 3. Energy expenditure in Expt $\mathrm{r}$ of four women at rest, before and after meals comprising (a) one-ninth, (b) one-third and (c) one-half of the daily calorie allowance

(Mean values per min with their standard errors)

(a)

\begin{tabular}{|c|c|c|c|c|c|c|}
\hline \multirow{3}{*}{$\begin{array}{l}\text { Time* } \\
\text { (min) }\end{array}$} & \multirow{3}{*}{$\begin{array}{c}\mathrm{kJ} \\
\text { Mean }\end{array}$} & & \\
\hline & & \multicolumn{2}{|c|}{ kcal } & \multirow{2}{*}{$\begin{array}{c}\mathbf{k J} \\
\text { Mean }\end{array}$} & \multicolumn{2}{|c|}{ kcal } \\
\hline & & Mean & $\mathrm{SE}$ & & Mean & $\mathrm{SE}$ \\
\hline- & $4^{\circ} 4^{8}$ & 1.07 & 0.08 & $4^{\circ} 56$ & I.09 & 0.1 I \\
\hline $3^{\circ}$ & $5 \cdot 23$ & $I \cdot 25$ & 0.20 & $5^{\cdot 65}$ & I'35 & 0.22 \\
\hline 60 & $5 \cdot 06$ & $I \cdot 2 I$ & 0.04 & $5 \cdot 27$ & $1 \cdot 26$ & 0.14 \\
\hline 90 & 490 & $x \cdot I y$ & 0.11 & $6 \cdot 32$ & I.5I & 0.22 \\
\hline 120 & $-\dagger$ & 一 & - & $5 \cdot 77$ & $I \cdot 38$ & 0.20 \\
\hline 150 & 5.06 & $I \cdot 21$ & 0.12 & $5 \cdot 65$ & I'35 & 0.21 \\
\hline 180 & 5.40 & $I \cdot 29$ & 0.15 & $5.4^{8}$ & $I \cdot 3 I$ & 0.23 \\
\hline 210 & 5.15 & $1 \cdot 23$ & 0.13 & - & - & - \\
\hline
\end{tabular}

from 0.72 to 1.55 and in (c) from 0.74 to $1.44 \mathrm{kcal}$ per min. There was no significant difference in response to the meals of different size under the conditions of this experiment. The control experiment without food for subjects D and S resulted in an increment in energy expenditure (deduced from the areas under the curves) of $\mathrm{r}_{4} \mathrm{kcal}$ $(59 \mathrm{~kJ})$, compared with $73 \mathrm{kcal}(305 \mathrm{~kJ})$ in $\operatorname{Expt~} \mathrm{I}(b)$ for these two women.

The urea excretion in Expt I $(b)$ reached a peak $29 \%$ above the pre-meal level I $20 \mathrm{~min}$ after the meal. The corresponding peaks were $42 \%$ at $210 \mathrm{~min}$ in Expt $\mathrm{I}(c)$ and $10 \% 60$ min after the second 'nibble' in Expt I (a). In the control expenditure 
with subjects $\mathrm{D}$ and $\mathrm{S}$ their urea excretion was $12 \%$ below the pre-meal level at the same time that the peak was obtained in $\operatorname{Expt~} \mathrm{I}(c)$.

The four women rested throughout Expts $2(a)$ and $(b)$ but took two 30 min walks at $5.3 \mathrm{~km} / \mathrm{h}$ in Expt $2(c)$. The results are given in Table 4 expressed in the same manner as in Table 3. The differences between individual subjects were greater than the

Table 4. Energy expenditure in Expt 2 of four women before and after meals comprising (a) one-third and (b) and (c) one-half of the daily calorie allowance

(In $(a)$ and $(b)$ resting conditions were rigidly controlled; in $(c)$ exercise preceded and followed the meal. Mean values per min with their standard errors)

(a)

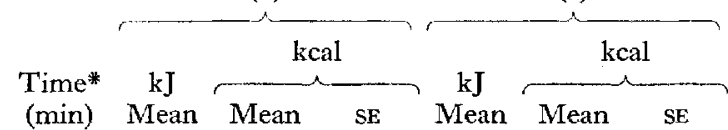

Fasting

After meals

\begin{tabular}{|c|c|c|c|c|c|c|c|c|c|}
\hline \multirow[b]{2}{*}{$\begin{array}{l}\text { Time* } \\
\text { (min) }\end{array}$} & \multirow[b]{2}{*}{$\begin{array}{c}\mathrm{kJ} \\
\text { Mean }\end{array}$} & \multicolumn{2}{|c|}{ kcal } & \multicolumn{3}{|c|}{$\mathrm{kcal}$} & \multirow[b]{2}{*}{$\begin{array}{c}\mathbf{k J} \\
\text { Mean }\end{array}$} & \multicolumn{2}{|c|}{ kcal } \\
\hline & & Mean & $\mathrm{SE}$ & $\begin{array}{c}\mathrm{kJ} \\
\text { Mean }\end{array}$ & VIean & $\mathrm{SE}$ & & Mean & $\mathrm{SE}$ \\
\hline- & 4.06 & 0.97 & 0.12 & 3.72 & 0.89 & 0.07 & $3 \cdot 68$ & 0.88 & 0.07 \\
\hline 20 & $4 \cdot 69$ & $1 \cdot 12$ & 0.09 & $4 \cdot 64$ & $I \cdot I I$ & $0 \cdot 0_{3}$ & $4^{\circ} 94$ & $I \cdot I 8$ & 0.07 \\
\hline 40 & 4.98 & $I \cdot 19$ & 0.13 & $4^{\cdot 98}$ & I. I 9 & 0.04 & 4.90 & $I \cdot I 7$ & 0.05 \\
\hline 60 & $5 \cdot 19$ & $r \cdot 24$ & 0.12 & $5 \cdot 36$ & $1 \cdot 28$ & 0.06 & $-t$ & $\square$ & - \\
\hline 90 & 4.98 & $I * I 9$ & 0.10 & $5 \cdot 23$ & $I \cdot 25$ & 0.12 & $5 \cdot 23$ & $1 \cdot 25$ & 0.09 \\
\hline 120 & $4 \cdot 3 \pi$ & $I^{\circ} \mathrm{O} 3$ & $0 \cdot 16$ & $4 \cdot 8 I$ & $I \cdot I 5$ & 0.08 & $5 \cdot 23$ & $I \cdot 25$ & 0.07 \\
\hline 150 & $4 \cdot 3 I$ & $I \cdot 0_{3}$ & 0.14 & 4.69 & $I \cdot I 2$ & 0.13 & - & - & - \\
\hline 180 & $4 * 35$ & $I .04$ & 0.10 & 4.60 & I.10 & 0.08 & - & - & - \\
\hline 210 & 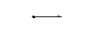 & - & -- & 4.77 & $I \cdot I 4$ & O.I I & - & - & - \\
\hline 240 & - & - & - & $4 \cdot 56$ & I.Og & 0.08 & - & $-\ldots$ & - \\
\hline 270 & - & - & - & $4 \cdot 56$ & I 09 & 0.11 & - & - & - \\
\hline 300 & - & - & $\cdots$ & $4^{\circ} 48$ & I.07 & 0.12 & - & - & - \\
\hline
\end{tabular}

(c)

* Time from mid-point of each meal for each subject.

$\dagger$ Second period of exercise in Expt $2(c)$.

Table 5. Energy expenditure in Expt 3 of five women before and after a $900 \mathrm{kcal}(3 \cdot 77 \mathrm{MY})$ meal, (a) with complete rest, (b) with exercise and (c) in a control experiment with exercise but no food

(Mean values per min with their standard errors)

(a)

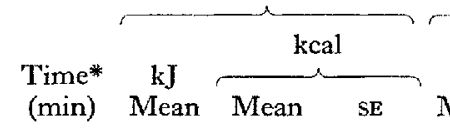

(b)

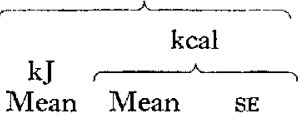

$0.03 \quad 3.47 \quad 0.83 \quad 0.04$

0.05

0.02

0.05

0.04

0.03

$0^{\circ} .3$

0.03

0.05

0.01

0.03

\section{$4.77 \quad I \cdot I 4 \quad 0.05$}

$4.69 \quad$ I.I 5

$-1$

$5.02 \quad 1.20$

$4.52 \quad 1.08$

$4.48 \quad I .07$

$4 \cdot 48$

$3 \cdot 85$

4.06

$3 \cdot 93$

$3 \cdot 8 \mathrm{I}$

1.07

$\begin{array}{ll}0.92 & 0.03\end{array}$

$0.97 \quad 0.05$

0.94 . 0.05

$0.91 \quad 0.03$ (c)

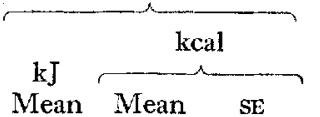

$\begin{array}{lll}3.56 & 0.85 & 0.06\end{array}$

$\begin{array}{lll}3.77 & 0.90 & 0.04\end{array}$

$\begin{array}{lll}3.56 & 0.85 & 0.04\end{array}$

$+\quad-$

$\begin{array}{lll}3.77 & 0.90 & 0.04\end{array}$

$\begin{array}{lll}3.39 & 0.81 & 0.04\end{array}$

$\begin{array}{lll}3.43 & 0.82 & 0.04\end{array}$

* Time from mid-point of each meal for each subject.

$\dagger$ Second period of exercise in Expts $3(b)$ and $(c)$. 
responses due to size of meals or exercise when the energy was expressed as $\mathrm{kcal} / \mathrm{min}$. For subjects $\mathrm{D}$ and $\mathrm{S}$, who underwent a control experiment (identical to Expt $2(c)$ but without food), the mean increment in Expt 2 (c) was $23 \mathrm{kcal}(96 \mathrm{~kJ})$ during 90 min following the meal compared with $4 \mathrm{kcal}(\mathrm{I} 7 \mathrm{~kJ})$ in the control experiment.

The results for Expt 3 are given in Table 5. The effects of the exercise in Expt $3(b)$ were insignificant (as in Expt 2(c)). The results of $\operatorname{Expt} 3(c)$ with exercise but no food, were significantly different from those of Expt $3(b)$ at 40,90 and $150 \mathrm{~min}$ after the meal $(P<0.01)$ and at 20 and $120 \mathrm{~min}(P<0.02)$.

Table 6. Cumulative response (kcal/period) to meals and exercise in the three experiments based on areas under the curves of calorie output using the results in Tables 3,4 and 5

(Mean values with their standard errors)

\begin{tabular}{|c|c|c|c|c|c|c|c|c|c|}
\hline \multirow{2}{*}{$\begin{array}{l}\text { Length of } \\
\text { period (min) }\end{array}$} & \multicolumn{3}{|c|}{ Expt I } & \multicolumn{3}{|c|}{ Expt 2} & \multicolumn{3}{|c|}{ Expt 3} \\
\hline & (a) & (b) & (c) & (a) & (b) & $(c)$ & (a) & (b) & (c) \\
\hline 90 & $\mathbf{I I} \pm \mathbf{I}$ & $18 \pm 10$ & $I 3 \pm 6$ & $17 \pm 2$ & $25 \div 4$ & $25 \pm I$ & $22 \pm \mathrm{I}$ & $24 \pm 3$ & $2 \pm 1$ \\
\hline 120 & —* & $29 \pm 12$ & $23 \pm 4$ & $2 I \pm 2$ & $34 \pm 4$ & $3^{6} \pm 2$ & $28 \pm 4$ & $33 \pm 3$ & $2 \pm I$ \\
\hline 150 & $15 \pm 6$ & $37 \pm 16$ & $32 \pm 6$ & $23 \pm 3$ & $42 \pm 5$ & - & $34 \pm 2$ & $41 \pm 3$ & $\mathbf{I} \pm \mathbf{I}$ \\
\hline 180 & $20 \pm 8$ & $47 \pm \mathrm{r} 8$ & $29 \pm 6$ & $25 \pm 3$ & $48 \pm 5$ & - & $39 \pm 4$ & $4^{8} \pm 4$ & - \\
\hline 210 & $25 \pm 12$ & - & - & - & $55 \pm 5$ & - & $44 \pm 4$ & $53 \pm 4$ & - \\
\hline 300 & $\ldots$ & $-\cdot \cdot$ & - & - & $75 \pm 9$ & - & $54 \pm 5$ & $63 \pm 5$ & - \\
\hline
\end{tabular}

In Table 6 the results of the three experiments are expressed as a cumulative caloric increment following each meal. The only significant differences in Table 6 are in Expts $2(a)$ and $(b)$ at 150 and 180 min after the meal $(P<0.05)$, when the effect of the smaller meal was declining. 'The calorigenic effect of exercise in the control Expt $3(c)$ was negligible.

The energy expenditure while walking at $5 \cdot 3 \mathrm{~km} / \mathrm{h}$ ranged from $2 \cdot 89$ to $4 \cdot 20 \mathrm{kcal} /$ $\min (12 \cdot 1-17 \cdot 6 \mathrm{~kJ})$ for the eight subjects in Expts $2(c), 3(b)$ and $(c)$. During exercise in Expts $2(c)$ and $3(b)$ seven of the eight women expended slightly more energy after the meal than before the meal, but in all subjects there was a small decrease in energy expenditure during the second walk when no food was taken in Expt $3(c)$. In Expt 3, however, the mean values for the four walks were not significantly different. They were 3.40 and $3.50 \mathrm{kcal}(14.2$ and $14.6 \mathrm{~kJ}$ ) per min for the first and second walks in Expt $3(b)$ and 3.58 and $3.46 \mathrm{kcal}\left({ }^{\circ} 5^{\circ}\right.$ and $14^{\circ} 5^{\mathrm{kJ}}$ ) per min respectively in $\operatorname{Expt} 3(c)$.

\section{DISCUSSION}

The first experiment was planned as a direct follow-up of a balance study in which the metabolic response to the frequency of meals was measured (Swindells et al. 1968). Because of the high cost in time and materials of human metabolic studies (King \& Calloway, I969), it is customary to make as many measurements as is possible during one experiment. This practice has its limitations, and in Expt I the apparent lack of difference in response to meals ranging from one-ninth to one-half the daily calorie allowance may have been due to the variable factors within the experimental design. 
With the combined effects of the ingestion of food and a large volume of water $\left(\mathrm{I}^{\cdot} \mathbf{4}^{-}\right.$ 2.41 consumed between 07.00 and 13.00 hours) some subjects felt discomfort causing them to be restless both while up-and-about and while lying down. Rest was interrupted each $30 \mathrm{~min}$ by the collection of urine for the measurement of urea excretion. The calorie allowance on which the size of meals was based, was different for each subject since the individual size of meal used in the balance study (Swindells $e t a l$. 1968) was repeated in Expt $\mathrm{I}$.

In the second experiment an attempt was made to eliminate some of the variable factors; the ingestion of water and the collection of urine were discontinued and the size of meals was based on a daily allowance of $1800 \mathrm{kcal}(7.53 \mathrm{MJ})$ for the two lighter women and $2400 \mathrm{kcal}(10.04 \mathrm{MJ})$ for the two heavier subjects. The subjects reclined for $5 \mathrm{~h}$ in Expt $2(a)$ and for $7 \mathrm{~h}$ in Expt $2(b)$. Even with these changes in experimental design the individual differences in response of the subjects were greater than the influence of the size of the meals, which confirmed our previous observations of large individual differences in metabolic response in such experiments (Swindells $e t$ al. rg68). The range of results, however, is similar to that of Miller, Mumford \& Stock (1967), even though their subjects (three men and three women) were overeating. They reported responses of $19-34 \%$ above the fasting metabolic rate 60 mir after the meal for six subjects eating meals ranging in size from 710 to $1040 \mathrm{kcal}(2 \cdot 97-4 \cdot 35 \mathrm{MJ})$. The corresponding result in our experiment was a range in response of $2 \mathrm{I}-40 \%$ above the fasting metabolic rate for four women each on two levels of meal size between 600 and $1200 \mathrm{kcal}(2 \cdot 5 \mathrm{I}-5.02 \mathrm{MJ})$. Although the response by individual subjects $60 \mathrm{~min}$ after the meal was unrelated to the size of the meal, each individual gave a greater response to a larger food intake.

It was not possible for the same subjects to take part in the three experiments, and this accounted for the difference in range in fasting resting metabolism between Expt I

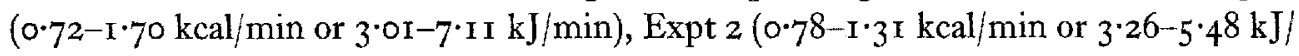
min) and Expt 3 (0.70-r.or kcal $/ \mathrm{min}$ or $2.93-4.23 \mathrm{~kJ} / \mathrm{min})$. Subject D, who took part in Expts $\mathrm{I}$ and 2 but not in Expt 3, had a consistently high rate of energy expenditure in all measurements.

For subjects D and S, who took part in both Expts $\mathrm{I}$ and 2, the energy increment during $3 \mathrm{~h}$ following each meal was unrelated to the size of the meal in Expt $\mathrm{I}$, though it was greater for the larger food intake in Expt 2. The respective mean increments during $3 \mathrm{~h}$ for subjects $\mathrm{D}$ and $\mathrm{S}$ were 73, 26, 25 and $4 \mathrm{I} \mathrm{kcal}(304, \mathrm{IO}$, I06 and $\mathrm{I} 72 \mathrm{~kJ}$ ) in Expts $I(b),(c), 2(a)$ and $(b)$.

Expt 2(c) was introduced to test the observation of Miller et al. (1967), with their overfed subjects, that the thermogenic effect of a meal is greatly increased during exercise after the intake of food. Their subjects exercised at the rate of twelve steps of I I in $(28 \mathrm{~cm}) / \mathrm{min}$, which for our subjects was equivalent to walking on a treadmill at $5.3 \mathrm{~km} / \mathrm{h}$. During both the exercise and the subsequent rest we observed no significant increase in response to the meal as a result of the exercise.

Expt 3 was designed primarily to test whether the greater caloric response of obese women after exercise and food as reported by Bradfield et al. ( $\mathrm{I} 968$ ) would be observed with women of lighter weight. The size of meal was standardized at $900 \mathrm{kcal}(3 \cdot 77 \mathrm{MJ})$, 
which was the size of the larger meal for subjects A and R in Expt 2. The effect of exercise on the metabolic response to meals was determined by measuring ( $a$ ) energy expenditure during exercise before and after meals (as used by Miller et al. 1967); (b) postprandial energy expenditure at rest with or without exercise (as carried out by Bradfield et al. I 968) and (c) energy expenditure during rest and exercise when no food was eaten.

The results of Expt $3(b)$ confirmed those of Expt 2(c); for measurements made during exercise the differences in oxygen utilization before and after the meal were insignificant. Also the postprandial energy expenditure at rest after exercise was not significantly different when compared to similar experiments without exercise. When the energy increment per hour was calculated, the mean results in Expts $3(a)$ and $(b)$ (Table 6) based on the first 90 min after the meal were $15 \mathrm{kcal}(63 \mathrm{~kJ}) / \mathrm{h}$ in the resting experiments and $\mathrm{I} 6 \mathrm{kcal}(67 \mathrm{~kJ}) / \mathrm{h}$ following exercise. Bradfield et al. (1968) reported a response of $17 \mathrm{kcal}(7 \mathrm{I} \mathrm{kJ})$ with obese women during the first $60 \mathrm{~min}$ of their $5 \mathrm{~h}$ of resting measurements while Miller et al. ( 1967$)$ observed a postprandial rise of I $8 \mathrm{kcal}(75 \mathrm{~kJ}) / \mathrm{h}$ for their overfed subjects in the resting state. However, the influence of exercise as reported by Miller et al. (1967) and by Bradfield et al. (1968) was not confirmed in our experiments.

The increment in energy expenditure after meals ranging in size from 600 to $1200 \mathrm{kcal}\left(2 \cdot 5 \mathrm{I}-5^{\circ} 02 \mathrm{MJ}\right)$ was small. In terms of total energy expenditure the specific dynamic action of food is an inconsiderable item in the energy metabolism of active people (Glickman, Mitchell, Lambert \& Keeton, I948; Passmore \& Ritchie, 1957; Davidson \& Passmore, r969). However, when measuring oxygen consumption over short periods of time it is important to standardize the conditions of rest, exercise and the timing of meals. Buskirk, Iampietro \& Welch (1957) stated that 'considerable variation may result unless measurements are made under well-controlled conditions with respect to food intake and time after meals', and found that the main response to food was due to the specific dynamic activity, whereas exercise and climatic conditions had a minimal effect.

The author wishes to acknowledge the willing co-operation of the ten subjects and to thank Miss W. Harding, Miss A. MeLean and Mr L. Cantwell for technical assistance and Associate-Professor M. F. Robinson for continual advice. The first experiment was carried out by Mr R. G. Rees under the guidance of Professor J. R. Robinson; the equipment for the study was provided by the Research Committee of the New Zealand University Grants Committee.

\section{REFERENCES}

Bradfield, R. B., Curtis, D. E. \& Margen, S. (1968). Am. J. clin. Nutr. 21, 1208.

Buskirk, E. R., Iampietro, P. F. \& Welch, B. E. (1957). Metabolism 6, 144.

Davidson, S. \& Passmore, R. (1969). Human Nutrition and Dietetics $4^{\text {th }}$ ed. Edinburgh: E. \& S. Livingstone.

Glickman, N., Mitchell, H. H., Lambert, E. H. \& Keeton, R. W. (1948). F. Nutr. 36, 4r.

Holmes, S. A., Swindells, Y. E., Sharpe, S. J., Wright, J. N. \& Robinson, M. F. (I969). Ұ. Am. diet. Ass. 54, 39. 
King, J. C. \& Calloway, D. H. (1969). F. Am. diet. Ass. 55, 361 .

Miller, D. S., Mumford, P. \& Stock, M. J. (I967). Am. Y. clin. Nutr. 20, 1223.

Passmore, R. \& Ritchie, F. J. (1957). Br. $\%$. Nutr. II, 79.

Rees, R. G. P. (1967). The effects of meals of different sizes on oxygen consumption and excretion of urea in urine in women. B. Med. Sci. Thesis, University of Otago, New Zealand.

Sharpe, S. J. \& Robinson, M. F. (1970). Br. F. Nutr. 24, 489.

Southgate, D. A. T. \& Barrett, I. M. (1966). Br. $\mathscr{~} N u t r .20,363$.

Swindells, Y. E., Holmes, S. A. \& Robinson, M. F. (Ig68). Br. F. Nutr. 22, 667.

Weir, J. B. de V. (1949). F. Physiol., Lond. 1o9, I. 